\section{Review of Tarping and a Case Study on Small-scale Organic Farms}

\author{
Roger Kubalek ${ }^{1}$, David Granatstein ${ }^{2}$, Doug Collins ${ }^{3}$, and \\ Carol Miles ${ }^{4}$
}

ADDiTIONAL INDEX WORDs. No-till, occultation, plastic mulch, stale seed bed, weed control

Summary. Covering the soil surface with opaque plastic sheets to kill vegetation is referred to as tarping and is used by small-scale and organic growers to control weeds before planting crops. There are few published studies on tarping, and here we present a review of the literature in combination with observations from two on-farm case studies, one carried out in northern California and the other in northwestern Washington. An advantage of tarping is that it enables growers to control weeds without herbicides or tillage equipment, which can be costprohibitive for small-scale growers. Tarping is also suitable for no- or reducedtillage systems, which is a primary goal for many small-scale and organic growers. Silage tarps that are 5 to 6 mils thick and black on one side and white on the other are most commonly used for tarping, are readily available new or used from some local agricultural suppliers or online, and can be reused for six or more seasons. Tarps are placed with the black side up to warm the soil, which encourages weed seed germination. When the soil is tilled and then tarped, a 3week period with sufficient soil temperature and moisture is sufficient to kill emergent weeds in the top $\approx 1$ inch of soil and provides a $95 \%$ to $100 \%$ weed-free surface at tarp removal. When a tarp is applied from autumn until spring to a plot that has established weeds, winter annual weeds can be controlled for several weeks after tarp removal, and then soil disturbance results in germination of additional weed seeds. For established perennial weeds, it may be necessary to extend the tarp application time to several months during critical weed growth phases or a full year to break the vegetative life cycle. Tarping does not reduce the weed seed bank, thus minimal soil disturbance after tarp removal is needed to maintain a reduced weed population during the cropping period.

$\mathrm{S}$ mall-scale farmers play a significant role in the local agricultural economy in many regions of the

Received for publication 11 Nov. 2021. Accepted for publication 16 Dec. 2021.

Published online 4 February 2022.

${ }^{1}$ Washington State University Global Campus, Pullman, WA 99164

${ }^{2}$ Washington State University Extension, Tree Fruit Research and Extension Center, $1100 \mathrm{~N}$ Western Avenue, Wenatchee, WA 98801

${ }^{3}$ Center for Sustaining Agriculture and Natural Resources, Washington State University, Puyallup Research and Extension Center, 2606 West Pioneer Avenue, Puyallup, WA 98371

${ }^{4}$ Department of Horticulture, Washington State University, Northwestern Washington Research and Extension Center, 16650 State Route 536, Mount Vernon, WA 98273

This work was supported by National Institute of Food and Agriculture Hatch projects 1017286 and 1014754.

C.M. is the corresponding author. E-mail: milesc@ wsu.edu.

This is an open access article distributed under the CC BY-NC-ND license (https://creativecommons. org/licenses/by-nc-nd/4.0/).

https://doi.org/10.21273/HORTTECH04991-21
United States. In 2017, the value of sales from small-scale vegetable farmers who sell locally and directly to consumers through farmers markets, community-supported agricultural subscriptions and restaurants in the United States was $\$ 2.8$ billion (O'Hara and Benson, 2019). Many small-scale farmers are certified organic or use organic practices, and account for a substantial portion of the certified organic producer population. In Washington State for example, the majority of certifiedorganic vegetable operations are in the category of 0 to 5 acres (65\%) with $12 \%$ in the next largest size category of 5 to 10 acres (Granatstein et al., 2018). For many small-scale and organic growers, weed management is one of the primary challenges for crop production (Bond and Grundy, 2001), and weed management strategies are commonly identified as a primary research need for organic production systems (Jerkins and Ory, 2016). Cultivation is the primary technique used for weed control by organic farmers, but many smallscale farmers are looking for effective and practical no- or low-till alternatives to cultivation for weed control (Schonbeck et al., 2017). In a survey of $\approx 100$ growers in the northeastern United States who have implemented tarps for weed control in their farming systems, more than $85 \%$ indicated reduced tillage was a primary objective (R. Maher, personal communication).

Tarping for occultation (blocking light from plants for extended periods of time) is a simple physical weed control method whereby the soil is covered with opaque plastic sheets to kill vegetation before planting crops. Tarping essentially creates a false or stale seedbed as weed seeds that have sprouted will die due to lack of sunlight when the tarp is put in place (Chandran et al., 2018). In a prepared bed system, tillage is carried out before tarping, the tarp is left in place for 3 weeks, and the tarp is removed immediately before planting to provide several weed-free weeks that allow the crop to become established (Birthisel and Gallandt, 2019; Caldwell and Mohler, 2001; Lounsbury et al., 2020; Rylander et al., 2020). The amount of time that the tarp is left in place will depend on soil temperature and can be shorter than 3 weeks in areas with higher temperature. In a no-till system, it may be necessary to leave the tarp in place for 5 to 12 months to kill perennial or biannual plants that have root reserves. Additional weed control

\begin{tabular}{llll}
\hline $\begin{array}{l}\text { Units } \\
\begin{array}{l}\text { To convert U.S. to SI, } \\
\text { multiply by }\end{array}\end{array}$ & U.S. unit & SI unit & $\begin{array}{l}\text { To convert SI to U.S., } \\
\text { multiply by }\end{array}$ \\
\hline 0.4047 & $\mathrm{acre}(\mathrm{s})$ & $\mathrm{ha}$ & 2.4711 \\
0.3048 & $\mathrm{ft}$ & $\mathrm{m}$ & 3.2808 \\
0.0929 & $\mathrm{ft}^{2}$ & $\mathrm{~m}^{2}$ & 10.7639 \\
2.54 & inch $(\mathrm{es})$ & $\mathrm{cm}$ & 0.3937 \\
0.4536 & $\mathrm{lb}$ & $\mathrm{kg}$ & 2.2046 \\
0.0254 & $\mathrm{mil}(\mathrm{s})$ & $\mathrm{mm}$ & 39.3701 \\
1.6093 & $\operatorname{mile}(\mathrm{s})$ & $\mathrm{km}$ & 0.6214 \\
2.2417 & $\operatorname{ton}(\mathrm{s}) / \mathrm{acre}$ & $\mathrm{Mg} \cdot \mathrm{ha}^{-1}$ & 0.4461 \\
$\left({ }^{\circ} \mathrm{F}-32\right) \div 1.8$ & ${ }^{\circ} \mathrm{F}$ & ${ }^{\circ} \mathrm{C}$ & $\left({ }^{\circ} \mathrm{C} \times 1.8\right)+32$
\end{tabular}

Horflechnology $\cdot$ April $202232(2)$ 
Table 1. Sources, costs, and dimensions for new silage tarps that are commonly used for weed control on small and organic farms; tarps are a petroleum-based product, and price fluctuates based on market conditions. This is not an all-inclusive list, and no endorsement of specific products is implied or intended.

\begin{tabular}{|c|c|c|c|c|c|c|c|}
\hline$\underline{\text { Source }}^{\mathrm{z}}$ & $\begin{array}{c}\text { Price } \\
(\$ / \text { item })^{y}\end{array}$ & $\begin{array}{c}\text { Estimated } \\
\text { shipping }(\$)\end{array}$ & $\begin{array}{c}\text { Price } \\
\left(\$ / \mathrm{ft}^{2}\right)^{x}\end{array}$ & $\begin{array}{c}\text { Thickness } \\
(\mathrm{mil})^{\mathrm{x}}\end{array}$ & $\begin{array}{l}\text { Width } \\
(\mathrm{ft})^{\mathrm{x}}\end{array}$ & $\begin{array}{c}\text { Length } \\
\text { (ft) }\end{array}$ & $\begin{array}{l}\text { Area } \\
\left(\mathrm{ft}^{2}\right)^{\mathrm{x}} \\
\end{array}$ \\
\hline KSI Supply & 303 & 150 & 0.09 & 11 & 50 & 100 & 5000 \\
\hline Blue Lake Plastics & 2000 & 500 & 0.07 & 6 & 32 & 1200 & 38,400 \\
\hline Johnny's Selected Seeds & 290 & 80 & 0.07 & 6 & 50 & 100 & 5000 \\
\hline Farmers Friend & 290 & 99 & 0.07 & 6 & 50 & 105 & 5250 \\
\hline Farm Plastic Supply & 85 & 42 & 0.11 & 6 & 24 & 50 & 1200 \\
\hline Kooima & 180 & 77 & 0.06 & 5 & 40 & 100 & 4000 \\
\hline
\end{tabular}

${ }^{\mathrm{z}}$ KSI Supply (Plymouth, WI), Blue Lake Plastics (Sauk Center, MN), Johnny’s Selected Seeds (Winslow, ME), Farmers Friend (Centerville, TN), Farm Plastic Supply (Addison, IL), Amazon Prime (Seattle, WA), GrowOrganic (Grass Valley, CA), Kooima (Rock Valley, IA).

y Prices as of Nov. 2020 with delivery to Bellingham, WA.

${ }^{\mathrm{x}} \$ \mathrm{l} / \mathrm{ft}^{2}=\$ 10.7639 / \mathrm{m}^{2}, \mathrm{l} \mathrm{mil}=0.0254 \mathrm{~mm}, \mathrm{l} \mathrm{ft}=0.3048 \mathrm{~m}, \mathrm{lft}^{2}=0.9029 \mathrm{~m}^{2}$.

practices will be needed after tarp removal in both systems; thus growers must be aware of the limitations of tarping for weed control (Hunter et al., 2016; Mashingaidze et al., 1996; Rylander et al., 2020).

Tarps can be used to keep a planting schedule on track because they can prevent fields from becoming overly wet due to spring rains and can be removed immediately before planting thus preventing planting delays. Tarps can also be used to aid in the establishment of slow-germinating crops such as carrot (Daucus carota ssp. Sativus) and can be an alternative to flaming; market growers are sharing this information through online discussion groups and social media [e.g., YouTube (San Bruno, CA), Instagram (Menlo Park, CA)]. The tarp is applied for 3 weeks to a bed that is ready to plant, removed briefly while the crop is seeded, and the area is immediately covered again until crop emergence. Any weed seedlings that emerge during the 1 - to 2 -week period that it takes carrot to emerge will die from lack of light, and the tarp retains constant soil moisture that aids carrot seed germination. Timing of tarp removal is important so as not to damage the crop. The tarp is lifted after 1 week and daily thereafter to inspect for crop emergence and the tarp is removed at the first signs of carrot emergence. Failure to remove the tarp on time can reduce the stand of the carrot crop.

Tarping materials are readily available and affordable for small-scale growers, and growers who use tarping are discussing it through their online discussion groups and social media. However, there are only three published studies focusing specifically on tarping, Rylander et al. (2020), Lounsbury et al. (2020), and Birthisel and Gallandt (2019), and thus there is little extension information on the subject. There is a need for extension information so that accurate and helpful information on tarping is more available. This review provides an overview of the effects of tarping for weed control and soil health and includes a case study on tarp use. With few formal studies on tarping, the information is gathered from small-scale tarp users and the literature on plastic mulch, which is well established. The goal of this review is to provide foundational information about the use of tarping so that agricultural professionals and market growers have a more complete understanding of its potential and limitations.

\section{Tarp products}

Small-scale growers in the United States most commonly use silage tarps to tarp their soil. Silage tarps are black on one side and white on the other, and for silage, the white side typically faces out to reflect thermal radiation and the black side faces inward to create a fully opaque barrier to keep oxygenproducing algae from growing in the silage (Blok et al., 2000). Most growers who use silage tarps for weed control will place the black side up to enhance solar radiation collection and warm the soil. Although other fully opaque plastic sheets and materials can be used for tarping for weed control, silage tarps are readily available and are predictable, durable, and affordable. Silage tarps can be purchased new from online sources or from some local dairy and feed stores. When shipping is added to the purchase price, new tarps average $\$ 0.08 / \mathrm{ft}^{2}$, and with bulk discounts, the price can be slightly less than $\$ 0.06 / \mathrm{ft}^{2}$ (Table 1). Tarps are reusable and some growers report through social media that they use a tarp for six or more seasons before it needs to be replaced. Although the ultraviolet (UV) light rating on a tarp is typically 3 to 4 years, the extended tarp life is due to the intermittent and short periods of use and the sunlight intensity at the location where the tarp is used, both which reduce duration and intensity of UV exposure.

Silage tarp is 5 to 6 mils thick, and width starts at $10 \mathrm{ft}$ and increases variably to $50 \mathrm{ft}$. Length is typically in 50 - $\mathrm{ft}$ increments with $100 \mathrm{ft}$ being the most common. Tarp weight is an important consideration as larger rolls can be heavy and awkward to handle. A $50 \times 100-\mathrm{ft}$ roll of 5-mil silage tarp will weigh $\approx 120 \mathrm{lb}$, making it difficult and dangerous to handle without equipment or adequate labor. A $50 \times$ $100-\mathrm{ft}$ tarp will come folded in the $50-\mathrm{ft}$ dimension and rolled in the $100-\mathrm{ft}$ dimension. Thus, if a $20-\mathrm{ft}$ length is cut from the roll, it will unfold to $20 \times 50-\mathrm{ft}\left(1000 \mathrm{ft}^{2}\right)$ and will weigh $\approx 24 \mathrm{lb}$. Tarps that are 1500 to $2000 \mathrm{ft}^{2}$ will weigh $\approx 36-48$ $\mathrm{lb}$ and are generally as heavy as a single person can easily handle.

Large bulk grain sacks (commonly $3 \mathrm{ft}$ width by $3.5 \mathrm{ft}$ height) are made of the same durable black and white polyethylene as silage tarps, they can be cut open to serve as a tarp, and are suitable for growers who need small tarps. Recycled silage tarps and grain sacks can minimize costs while reusing materials. 
An organization in Canada [Simply Agriculture Solutions (now Clean Farms), Etobicoke, Canada] collects and recycles used silage tarps and grain sacks and will send a full semitrailer of these materials to some locations in the United States for the cost of shipping. For example, one load of used silage tarps and grain sacks was shipped to an incubator farm near Portland, OR, where tarps were used by 20 beginning farmers (Steele, 2017). There are challenges with using recycled silage tarps and grain sacks such as random sizes, minor damage/holes, and residual grain that can attract pests. Accepting a full semitrailer load of these materials also requires adequate offloading facilities and equipment.

Clear plastic is sometimes used for solarization and weed control in areas where temperatures greater than $45^{\circ} \mathrm{C}$ can be achieved under the plastic (Birthisel and Gallandt, 2019; Stapleton, 2000). When conditions are right for solarization, high temperatures reached under clear plastic are greater than under opaque tarps and can kill weed seeds as well as germinated weed seedlings (Birthisel and Gallandt, 2019; Dahlquist et al., 2007; Gill et al., 2017; Lounsbury et al., 2020). However, when conditions are not ideal for high temperature accumulation under plastic covers, such as in cooler northern climates and maritime regions that are characterized by persistent cloud cover, tarps can outperform clear plastic in providing a false seedbed. Under these conditions, weeds will germinate under the tarp then die due to lack of photosynthesis, whereas under clear plastic some weeds will be stimulated to grow by the slightly elevated temperature and the light (Birthisel and Gallandt, 2019; Lounsbury et al., 2020). Thus, opaque plastic such as white on black is suitable for tarping in every environment, whereas clear plastic only provides weed control in regions with high temperature.

\section{Application and removal}

The key to successful tarping is to first prepare the area for planting and then apply the tarp so that when the tarp is removed, there is as little soil disturbance as possible. Preparation includes any tillage, amendment application, and/or bed shaping. If a notill plot with a large amount of
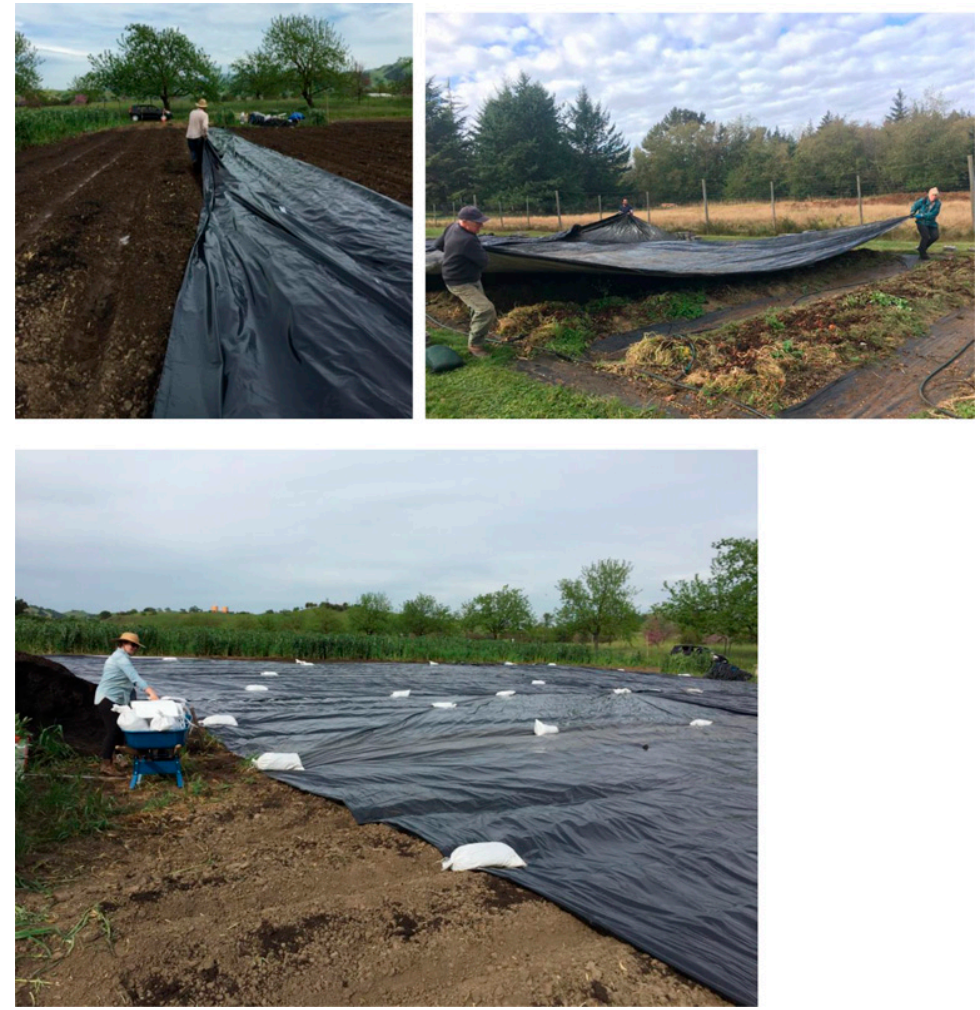

Fig. 1. Unfolding (top left) and pulling (top right) a tarp across a field plot and placing weights on the edges and the center of the tarp to keep it from being damaged or blowing away in strong winds (bottom).

vegetation is being tarped, the area should be mowed or rolled flat before tarping so that the tarp lies as close to the soil surface as possible. Soil moisture is needed for weed seed germination, thus a tarp placed over dry soil will not be as effective as when placed over moist soil. The tarp is unrolled along the edge of the plot that will be tarped, and two people working on opposite ends of the tarp will pull the tarp across the soil surface (Fig. 1). Weights are placed on the edges and center of the tarp to keep it in place through inclement weather (Fig. 1). Staples are not used because they create holes in the tarp and create a weak point where the tarp will rip under windy conditions. A $2000-\mathrm{ft}^{2}$ tarp will require $\approx 1000 \mathrm{lb}$ or more of weight to secure it, depending on how windy the area is.

Tarp removal can be done by one or two people on a calm, dry day using a series of folds that are in reverse order of application. Dry tarps free of plant and soil debris can be stored for many years if kept out of the sun. Rodents are attracted to loosely piled tarps and can cause extensive damage. Pallets can be used for storage and handling of tarps and the weight materials, and facilitate efficient transport around the farm with a forklift.

\section{Weed control}

Tarps are used primarily for weed control, and when applied to a tilled plot, weed seeds that germinate and emerge will become etiolated and chlorotic and begin to die after 1 to 2 weeks. Most growers keep the tarp in place for 3 weeks and after removal the soil surface is $95 \%$ to $100 \%$ weedfree (Birthisel and Gallandt, 2019; Caldwell and Mohler, 2001; Lounsbury et al., 2020; Rylander et al., 2020). Minimizing soil disturbance after the tarp is removed is needed to minimize exposure of weed seeds to light and subsequent germination during the cropping period (Boyd et al., 2006). The seeds of some species of weeds can have dormancy interrupted by a brief (i.e., 1 millisecond) exposure to sunlight, which can occur during soil tillage (Batlla and Benech-Arnold, 2014).

A common stale seed bed technique is to prepare the soil for planting, cover the area with a tarp, and after tarp removal use flame weeding 
to kill any remaining weed seedlings. Successive flushes of weeds can be encouraged with irrigation and additional 2-week tarp applications followed by flaming (Stone, 2015). Although some growers are using this technique of tarping followed by flaming, no published studies directly describe its efficacy. For example, Birthisel and Gallandt (2019) found that flaming after solarization did not further decrease weed pressure, thus more research is needed to determine how flaming can be most effectively paired with tarping.

Although tarping is effective to control germinating weed seedlings, it does not appear to reduce the weed seed bank, likely due to the large number of weed seeds present in soil (Hunter et al., 2016; Mashingaidze et al.,1996). For example, Rylander et al. (2020) determined that seed survival of the summer annual weeds powell amaranth (Amaranthus powellii) and common lambsquarters (Chenopodium album) was not reduced by tarping. In that study, fewer viable seeds of powell amaranth were counted under nontarped treatments at one sampling date, and the number of viable common lambsquarters seeds was the same in tarped and nontarped treatments. A study with plastic mulch used throughout the cropping season in northwest Washington also found no reduction in weed seed number or viability for all but one species of weeds found at this site (Seefeldt et al., 2019). In that study, oat grass (Arrhenatherum elatiusnutlets) nutlets were reduced by the plastic mulch treatment, indicating that some weed species can be controlled by plastic mulch, and a similar result is likely if a tarp is left in place for several months just as the plastic mulch was in that study.

When a tarp is applied to a plot that has established weeds, control will be dependent on weed species, season of application, environmental conditions, and tarping duration. Winter annual weeds can be controlled by applying the tarp from autumn until spring planting. However tarping applied for this same time period likely will not control summer annual weeds throughout the season as these weed species tend to have substantial weed seed banks and they germinate later in the summer after the crop has been planted. Rylander et al. (2020) identified amaranth (Amaranthus) species, which generally emerges in the summer after the crop has been planted, as one of the most abundant weeds present at harvest, although they measured a reduction in weed biomass in tarped plots compared with tilled and nontarped treatments.

Longer treatments or targeted timing are needed to reduce the more aggressive perennial weeds that have extensive root storage and durable shoot regrowth, such as field bindweed (Convolvulus arvensis), horsetail (Equisetum arvensis), bermudagrass (Cynodon dactylon), and dandelion (Taraxacum offcinale). In some cases where aggressive perennial weeds are present, it may be necessary to extend the tarp application time to several months during critical weed growth phases or a full year to break the vegetative life cycle. For example, field bindweed has extensive root storage and is often managed by frequent mechanical tillage in organic systems to reduce root reserves (Orloff et al., 2018). Canada thistle (Cirsium arvense) is another difficult weed to control due to its root storage and regrowth potential, and tillage can spread the roots, leading to further vegetative establishment (Jacobs et al., 2006). In a meta-analysis of control methods in organic systems, shading resulted in the greatest reduction of canada thistle; however, there were insufficient data to provide a confidence interval compared with the other methods that were included in the meta-analysis (Orloff et al., 2018). Research is needed to investigate timing and duration of tarping to control perennial weed species that have extensive root systems and root reserves.

\section{Cover crop management}

Many small-scale growers use cover crops to produce in situ plantbased mulch in no-till systems and to provide competition against weeds. Cover crops need to be terminated before planting the cash crop, and herbicides, mowing, tillage, or roller crimpers are often used to achieve this (Davis, 2010; Hoyt et al., 1994). In organic systems that rely on accurately timed crimping, regrowth of the cover crops that are often planted in mixtures may interfere with the cash crop (Luna et al., 2012). In this case, the cover crops become a weed in the system and can compete with cash crops or cause challenges with planting or harvesting activities. Cover crops that are not effectively terminated can also produce seeds that present a volunteer weed problem in future seasons. Tarps can be used to terminate cover crops when crimping alone is not sufficient. For example, Lounsbury et al. (2020) found that vetch (Vicia villosa) regrew after roller crimping but complete control was attained by tarping. Some growers are successfully using tarping to terminate cover crops without heavy crimping equipment. When the cover crop reaches the amount of growth the grower would like to attain, the cover crops can be manually laid flat by lightweight equipment such as a water weighted lawn roller or homemade tools. Tarps are then applied for an average of 3 weeks to terminate the cover crops; less time may be needed in areas with higher temperature. This is a distinct advantage for tarp usage especially for small-scale or beginning farmers who do not have heavy equipment.

The effects of tarping on crop residue decay have been variable and warrant further research. For example, Rylander et al. (2020) used a beaded string method to evaluate oat cover crop residue in tarped and nontarped plots and found residue remained more intact under tarps. In contrast, Lounsbury et al. (2020) measured rye (Secale cereale) cover crop biomass before and after tarping and reported increased cover crop degradation under the tarp compared with noncovered and clear plastic treatments. This was attributed to more stable environmental conditions under the tarped area that promoted biological activity compared with noncovered where environmental conditions were less stable and more extreme conditions under clear tarps. Residues that are on the soil surface after tarp removal can be raked off or left in place as a mulch.

\section{Soil effects}

For tarping to be effective, there must be adequate soil moisture in the top few inches of soil to stimulate weed growth and for weed seed germination. Rylander et al. (2020) found that soil moisture was greater with tarps in 5 of 10 experiments, whereas in 3 of the 10 experiments soil moisture was elevated but not significantly so, and in the remaining two experiments soil 
moisture was equivalent. A study comparing solarization with clear plastic and black plastic tarps showed soil moisture under black plastic tarps was similar to adjacent noncovered soil (Birthisel and Gallandt, 2019). Tarps can exclude water infiltration from rain events, keeping the soil moisture more constant over time compared with bare ground (Lounsbury et al., 2020). A 2year study with plastic mulch in raspberry (Rubus idaeus) production showed there was lower volumetric water content in mulched beds compared with no mulch, suggesting that plastic mulch prevented rainfall from percolating into the soil (Zhang et al., 2020). In areas with heavy winter and spring rains, keeping soils from becoming overly wet can be helpful for early planting. However, if a large area is covered with impermeable tarps then water runoff and potential edge erosion must be considered.

Temperature in the top few inches of soil is another important factor for effective tarping. Tarping increased soil temperature by 1 to $6^{\circ} \mathrm{C}$ during the spring period in two tarping experiments compared with noncovered ground (Birthisel and Gallandt, 2019: Rylander et al., 2020). In those experiments, the maximum soil temperature under black tarp was $\approx 30^{\circ} \mathrm{C}$, whereas under clear plastic, it was 45 to $50{ }^{\circ} \mathrm{C}$. In an experiment where tarps were laid over a thick layer of crimped rye mulch, the maximum soil temperatures were lower under black plastic tarp than under clear plastic and noncovered treatments (Lounsbury et al., 2020). The authors speculated that the airgap created by the rye mulch likely had an insulator effect on the soil temperatures. Direct plastic contact with the soil may be necessary to increase soil temperature (Lamont, 2005).

Tarping studies to date have not measured physical soil characteristics such as bulk density and aggregation. However, there is extensive literature from field experiments using plastic mulch, and effects will likely be similar for tarps that are left in place for several months, similar to the duration of mulch. Soil physical properties such as soil water-stable aggregate content are improved under plastic mulches compared with bare ground (DomagałaSwiątkiewicz and Siwek, 2018; Sintim et al., 2021; Wang et al., 2017). A study that evaluated long-term effects in fields where plastic mulch was in place for 2 to 20 years showed improved aggregate stability compared with plots where the mulch had been removed (Meulen et al., 2006). Javeed et al. (2013) similarly found that plastic mulch reduced soil bulk density and increased aeration compared with nonmulched plots. Further, soils under plastic mulch had increased temperature, moisture, and aeration, which fostered increased microbial activity for nitrification (Kasirajan and Ngouajio, 2012). Lounsbury et al. (2020) observed increased cover crop residue degradation and increased yields in no-till cabbage (Brassica oleracea ssp. Capitata) after tarps were in place for 2,4 , and 5 weeks compared with noncovered beds and speculated that this was due to increased microbial nutrient mineralization in the soil. For example, soil nitrate levels increased with increased tarping duration before planting no-till beet (Beta vulgaris) (Rylander et al., 2020), and soil nitrogen mineralization increased, whereas leaching was reduced with plastic mulches (Jones et al., 2020; Mo et al., 2020; Sintim, et al., 2021; Zhang et al., 2012). These results indicate that through physical, chemical, and biological processes, available nitrogen, an important agronomic nutrient, is promoted by plastic mulches and could also be increased by tarps.

Tarping impacts on soil organic carbon and $\mathrm{pH}$ have not been reported. However, tarping may reduce labile carbon in the soil as elevated temperatures have been shown to promote accelerated labile carbon decomposition (Qi et al., 2016). The use of high carbon materials such as cover crops, manure, or compost by many smallscale and organic growers may offset the impact of tarping on soil labile carbon (Hu et al., 2018). In regard to soil $\mathrm{pH}$, large changes from plastic mulching have not been reported, although temporarily increased nitrate presence in the soil from mulching has been shown to decrease soil $\mathrm{pH}$ slightly (Wang et al., 2017). Similarly, Sintim et al. (2019) found a tendency toward declining $\mathrm{pH}$ in plastic mulched soils although the results were not consistent across all seasons. Thus, soils on the verge of being too acidic for general crop production may need to be monitored when tarped and amended with lime to avoid further decreases in $\mathrm{pH}$ especially when tarps are left in place for several months or longer.

Tarps likely alter the soil gas levels compared with noncovered ground, and more research is needed to understand how this might affect soil biology and chemistry. Tarps used for silage production have a low oxygen permeability to reduce aerobic spoilage of the ensiled forage (Borreani et al., 2014). A microplot field experiment showed that when white-on-black silage tarps were kept in place for 3 to 5 weeks, gas levels began to normalize 3 weeks after the plastic was removed with no organic material incorporation and after 8 weeks with organic material incorporation (Blok et al., 2000; Messiha et al., 2007). Shahzad et al. (2019) determined that although plastic mulch affected gas diffusion between the soil and atmosphere, the soil oxygen concentrations never fell below $16 \%$, thus there was no negative impact on aerobic soil microbes. Most growers who use tarps do not bury the tarp edges, which might allow enough gas exchange to prevent prolonged anaerobic conditions. Further, small holes that are made in tarps over time from usage may also help prevent anaerobic conditions (Messiha et al., 2007).

Additional information is needed to assess whether soil physical and chemical changes resulting from tarping affect soil biology or habitability for beneficial organisms or invertebrate pests. Temperatures and moisture levels under plastic mulch are moderated, which may promote more stable conditions that lead to enhanced microbial activity (Sing, 2013). However, a study in a relatively cool northeast U.S. climate where solarization using clear plastic was compared with tarping using black plastic did not find a difference in soil microbial activity due to the plastic treatments, and both were similar to the noncovered control (Birthisel et al., 2019). Soils under tarps become void of living vegetation within a few weeks, which could create significant temporal and spatial effects for invertebrates. For example, slugs [e.g., black slug (Arion ater), grey field slug (Deroceras reticulatum)] are a major agricultural pest and have a strong preference for living plant food (Kozłowski and Kozłowska, 2008), and populations could potentially be reduced by tarping. Additional information is needed to assess whether soil 
microbial communities, soil-dwelling beneficial organisms, or agricultural pests are negatively affected by tarping under different climates. More information is also needed to determine how quickly a tarped area becomes colonized by previously excluded organisms and if there is a lag phase that allows the crop to escape predation and become established. These questions deserve further study to understand more of the ecological impacts that tarping may have on a relatively small and localized scale.

\section{Tarping experiences on two small-scale farms}

Given the limited research studies and outreach information regarding tarping, the lead author, who is a small-scale grower, carried out a case study on two farms on the west coast. The objective of the case study was to observe and record the effectiveness of tarping for weed control in small-scale vegetable production systems. One farm was in the Sunol AgPark in northern California and the second was Full Bloom Farm on Lummi Island in northwestern Washington. The locations have different climate and soil types as well as different weed populations and management strategies (tilled and no-till, respectively). Heuristic (hands-on learning) approaches to ecological weed management are common among growers, who often learn by trial and error (Zwickle et al., 2014), and these two on-farm tarping experiences provided insights into tarping techniques and effectiveness.

Northern California ONFARM EXPERIENCE. The Sunol AgPark in northern California is characterized by a Mediterranean climate with relatively short wet winters and extended warm, dry summers. The average annual rainfall is 15 to 24 inches that falls predominantly through the winter months. There is a long growing season with a frost-free period typically between 260 and $360 \mathrm{~d}$. Average temperatures for this location during the growing season are maximum 84 to 87 ${ }^{\circ} \mathrm{F}$ and minimum 55 to $60{ }^{\circ} \mathrm{F}$. The soil is characterized as a well-draining Yolo loam that is highly productive when irrigated. The land has been managed for organic vegetable production since Sunol AgPark was established in 2006, with several operators leasing land and managing it using their own preferences within the guidelines of the National Organic Program.

The tarping experiment was carried out at this location in the 2017 growing season. Tarps were used to create a stale seedbed following conventional tillage and bed shaping in an effort to minimize early weed pressure. The field was disked in the autumn with two passes of a tandem disk and ring roller harrow, then a cover crop consisting of a mixture of rye, oat (Avena sativa), and bell bean (Vicia faba) was broadcast planted. Soil moisture came from winter rains and the cover crop grew until late March when it was mowed. Compost was applied to the field at $\approx 4$ tons/acre, the field was disced twice and then tilled with a rotary tiller to break up clods left by the disc. This tillage process is used by other organic growers at this location and is representative of a tillage-based system for small-scale organic vegetable growers throughout the United States. On 5 Apr., beds were shaped with a disc bedder pulled behind a tractor, irrigation was applied to the beds to encourage weed germination, and the field was covered with tarps that were weighted with sandbags filled with compost.

Tarps were lifted 2 weeks after application to inspect the soil surface and germinated weed seedlings were found to be etiolated and chlorotic. When tarps were removed after 4 weeks, the only remaining plants were chlorotic field bindweed. Figure 2 shows field bindweed at the time of tarp removal and 6 weeks later. Field bindweed also regrew when tarps were removed after 15 weeks for later-succession plantings. In addition to rhizomes, field bindweed has deep vertical roots that can extend $4.3 \mathrm{~m}$ deep and are capable of budding
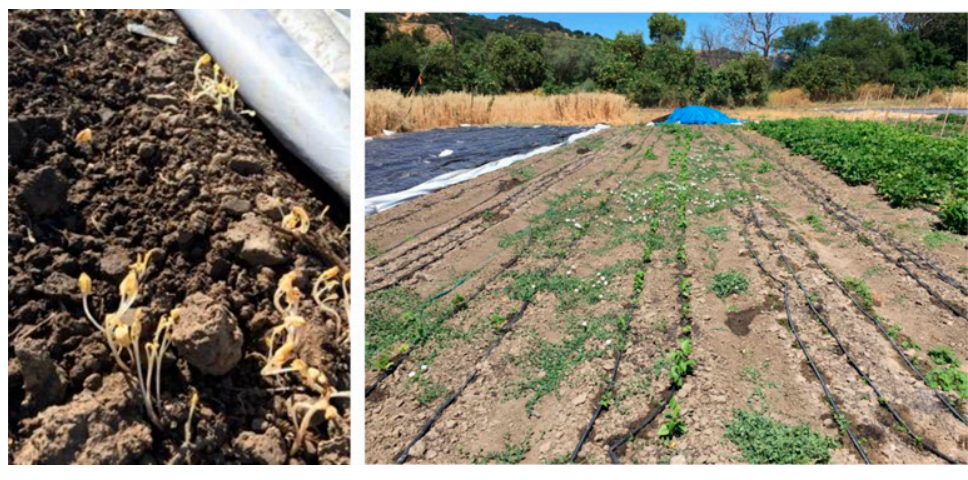

Fig. 2. Field bindweed was chlorotic when the tarp was removed after 4 weeks (left) but was well established 6 weeks after the tarp was removed (right). throughout the length of the root, although new shoots mostly emerge from the top $0.35-\mathrm{m}$ root section (Mitch, 1991; Willeke et al., 2015). Tarping may provide some control by encouraging bindweed roots to break bud and emerge in spring and summer, then roots are depleted of their reserves due to the lack of light and photosynthesis (Willeke et al., 2015). Other than field bindweed, the tarps provided a clean seedbed to plant into, which made planting activities easier. Cash crops planted included heirloom tomato (Solanum lycopersicum), chili pepper (Capsicum annum, C. frutescens, and C. chinense), tomatillo (Physalis philadelphica), and green bean (Phaseolus vulgaris). However, the tarps did not offer season-long weed control and extensive weeding activities were still necessary to keep the crops from being overtaken by summer annual weeds. Redroot pigweed (Amaranthus retroflexus) was especially difficult to control at this site. This site had been managed organically by growers with varying skill levels over the previous years and was abandoned for 2 years before tarping. The soil likely contained a large weed seed bank, but perhaps more importantly, redroot pigweed germination is enhanced by warmer temperatures (i.e., 25 to $30^{\circ} \mathrm{C}$ ), which typically occur later in the season at this site, after tarp removal (Oryokot et al., 1997). Field activities that disturb the soil after tarp removal, such as soil disturbance for planting and crop irrigation, promote weed germination, and these weeds need to be controlled with alternative methods.

Tarping had a positive effect on the soil physical condition during a critical period before planting. Tarps protected the soil during a heavy rain 
event shortly after the fields were tilled. Areas that were not covered by tarps were compacted by the rain and became heavily crusted, which needed to be broken up with additional surface tillage before planting. The soil in the tarped beds maintained a fine tilth and was evenly moist compared with the noncovered ground. Thus, the tarps protected the soil such that the planting area did not need to be reworked before spring planting, and this saved money and time.

NorthWEstern Washington ON-FARM EXPERIENCE. Full Bloom Farm is on Lummi Island in the Puget Sound, nearly 800 miles north of the California location. The Washington location has a cooler maritime climate characterized by extended cool, wet winters and mild summers. The average annual rainfall is 40 to 55 inches, which falls mostly throughout the winter months with potential for a few showers during late spring and early summer. The main growing season is shorter than northern California, with a frost-free period of 150 to $190 \mathrm{~d}$. Average maximum temperature during the summer is 68 to $72{ }^{\circ} \mathrm{F}$, and the minimum temperature is 52 to $55^{\circ} \mathrm{F}$. The soil is characterized as Hale silt loam and was formed by loess and volcanic ash over glacial outwash. The area is generally considered to be prime farmland. The field site was in pasture for several decades and converted to permanent raised beds for vegetable production 2 years before the tarping experiment that took place
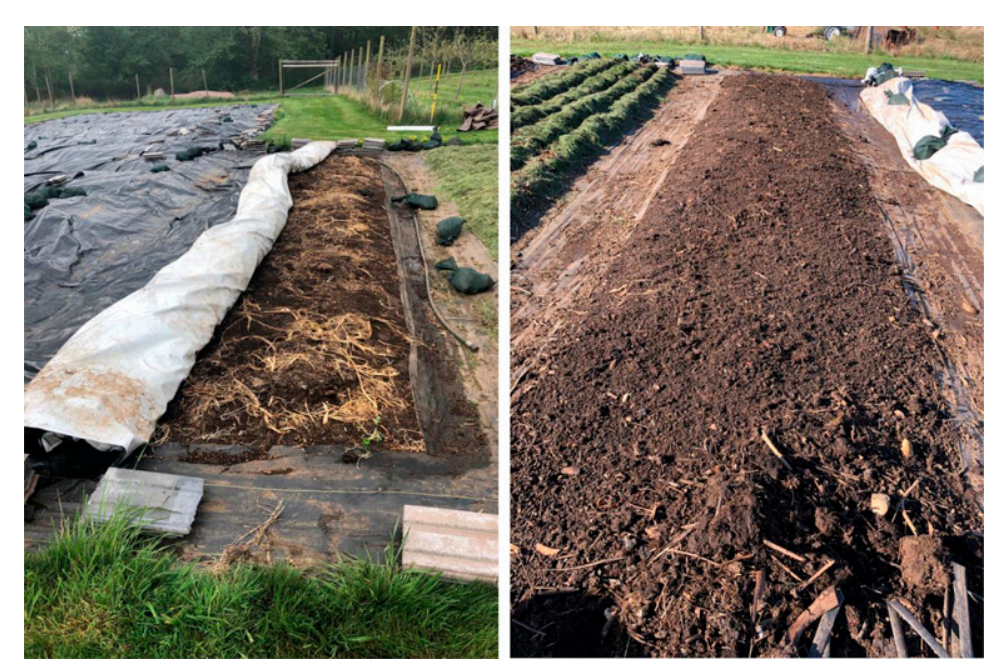

Fig. 3. Residue from the previous crop, grass clippings and mulch remained on the bed surface after 5 to 6 months of tarping (left) but was easily raked away to provide a clean bed for direct seeded crops (right).

from Autumn 2019 through the 2020 growing season.

Tarps were applied to permanent raised beds with the goal of preparing beds for spring planting without tillage and to protect the soil during the winter months when there was heavy rainfall. Bed preparations began in late Oct. and Nov. 2019 by top dressing with compost and grass clippings, with the previous crop debris and weeds left in place. Some tall and woody crop vegetation was cut and removed so that the tarps could be laid as close as possible to the soil surface. The beds remained covered with the tarps for $\approx 5$ months, with the first tarp removal in March to plant early vegetables. Tarp removal continued through the first weeks of June when the final plantings of summer crops occurred. When each tarp was removed, there was some crop debris remaining that was easily raked away to reveal a clean seedbed with virtually no weeds (Fig. 3). A green bean crop was handplanted with minimal soil disturbance by creating a 1 -inch-wide furrow the length of the planting row. Seeds were placed in the furrow 6 inches apart then firmed in place with a hoe (Fig. 4 ); in contrast, the normal procedure without tarping would be to rotary till the area several times before planting. Turnip (Brassica rapa ssp. Rapa) was also direct seeded into a weed-free planting bed by using a hoe to create a furrow $\approx 1$ inch wide by 0.5 inch deep, placing the seeds by hand into the furrow, and pulling the soil at the edges of the furrow back into the opening

Horflechnology • April $202232(2)$ with a hoe to close the furrow. Weed control was not season-long, and weeds that grew in the tarped beds during the summer were lady's thumb smartweed (Polygonum persicaria), shepherd's purse (Capsella bursa-pastoris), annual grasses (Poa sp.), common chickweed (Stellaria media), and some unidentified species in the sunflower (Asteraceae) family. Compost and grass clippings that were applied to the beds before tarping in the autumn likely contained viable weed seeds. Although weed growth was extensive by the end of harvest, turnip were fastgrowing, and yield was satisfactory both in number and size. Slower growing or less competitive crops likely would have been negatively impacted by weed competition. Horsetail (Equisetum sp.) survived under the tarps and emerged in some of the beds shortly after tarp removal in the spring. Although initially chlorotic, the horsetail grew throughout the summer. The timing of the tarping treatment coincided with the winter dormant period of horsetail, and tarping during the summer may be necessary to control this weed.

A tarp was applied to an established bed of peony (Paeonia lactiflora) that had become overgrown with weeds. Peony is perennial with a winter dormancy period. The plants were cut back at the ground to remove the previous year's growth, and a tarp was applied over the bed in late winter. The tarp was removed after 8 weeks, in early spring, as the peony plants began to grow (Fig. 5). The tarp killed most of the annual grasses that were growing in the bed and intertwined with the peony crowns, which reduced hand weeding labor. Dandelions were bleached but not killed and installing the tarp earlier, in the late summer or early autumn just after peonies were cut back, would allow for a longer tarping duration and may provide better weed control. The tarp could also be removed a little earlier, in late winter (mid to late February at this location) and so would be less likely to interfere with emerging peony shoots that begin growing early in the spring. Peony requires a minimum of 4 weeks of chill hours below $42{ }^{\circ} \mathrm{F}$ to bloom well (Fulton et al., 2001). A tarp placed with the black side outward can increase soil temperatures, and in areas 

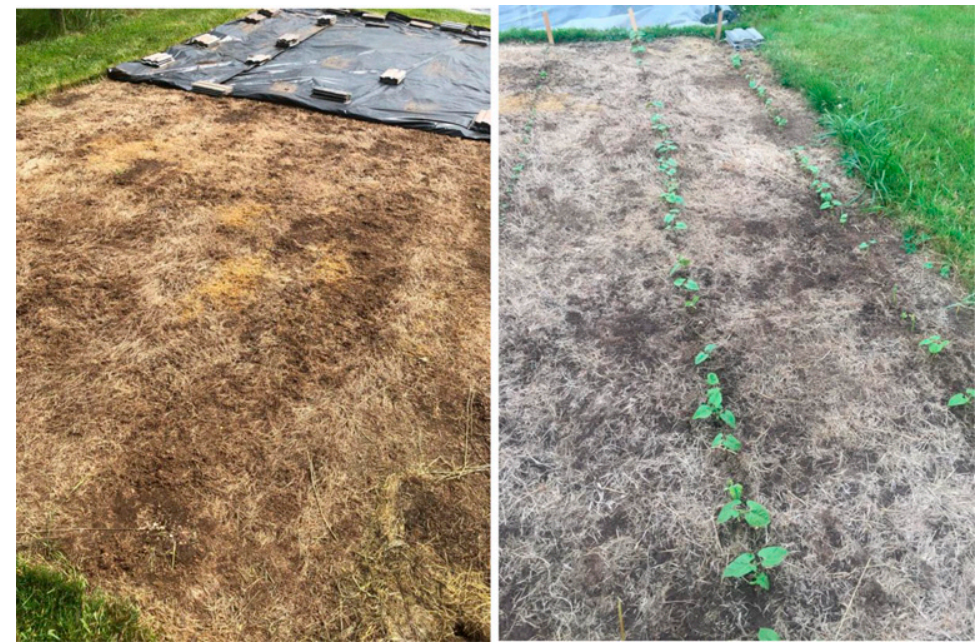

Fig. 4. A tarp was applied to a field of sod for 6 months and then removed (left), green bean was direct seeded, several weeks later there was very little weed competition as the crop became established (right).

with a mild winter climate such as northwest Washington, accumulated chill hours could be reduced below the threshold needed for bloom. Placing the tarp with the white side up may prevent an increase in soil temperature and preserve bloom (Lamont, 2005). Trials with organic peony production are ongoing at this site with the goal of determining the optimal timing for tarp placement and removal and whether there are any negative effects on crop yield and health.

Improved soil physical qualities were observed in the areas that had been tarped compared with bare soil. When

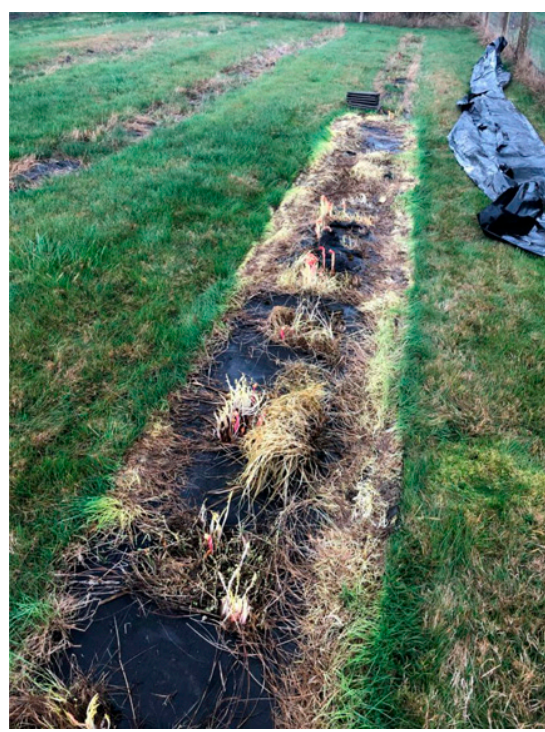

Fig. 5. A tarp placed over a peony bed in late winter was removed after 8 weeks in early spring, and weed competition was reduced in the bed. the tarps were removed there was a visually apparent aggregation on the soil surface in contrast to bare soil that was exposed to heavy winter rain and had increased crusting on the surface and required tillage for planting (Fig. 6). Although the tarping method was successful for growing crops, further work is needed to evaluate timing of tarp placement, crop yield, soil health, and pest pressure with this no-till method.

\section{Discussion and conclusions}

Tarping is an effective tool to aid small-scale growers to reduce initial weed pressure in vegetable and other crop production systems. Tarp application and use require little training or special tools to implement and can reduce the need for tillage and herbicides while providing a measure of predictability that is extremely valuable in an otherwise highly variable farming environment. Tarps are most commonly used to create a false/stale seed bed in tilled systems, and they also are effective in controlling established weeds or cover crops in reduced- and no-till systems. However, more research and outreach are needed to provide increased awareness and realistic expectations for growers regarding tarping for weed control. For example, research is needed to determine whether there are thresholds for thermal accumulation under the tarp that could be used to estimate crop emergence. A thermal accumulation threshold for carrot that are seeded and then covered with the tarp would provide growers the ability

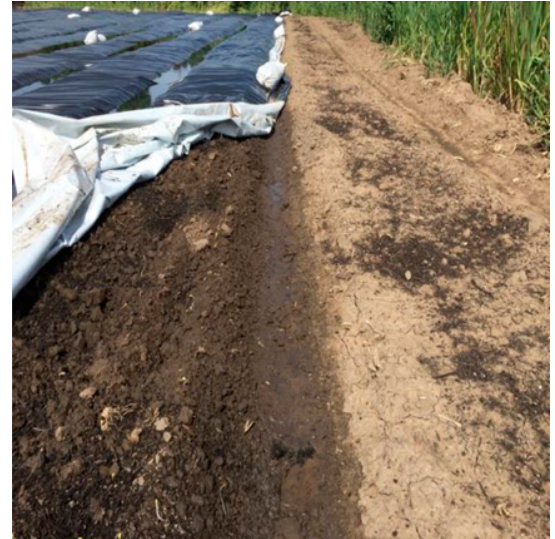

Fig. 6. After a heavy rain event, soil under the tarp was moist with good tilth (left) whereas noncovered ground was heavily crusted and required secondary tillage before planting (right).

to determine when to remove the tarp without having to check for emergence under the tarp every day. There is a cost associated with tarp materials and the labor needed to apply and remove the tarps. Although used silage tarps are widely available in many locations and can provide an affordable material for tarping, there are no economic studies that document the costs and returns for tarping.

Tarps control weeds for the first few weeks after they are removed; however, an integrated strategy is needed to control perennial weeds and weeds that emerge later in the growing season. Few formal studies have reported impacts of tarping in crop production systems; therefore, additional studies are needed to understand tarping positive and negative impacts in association with various soil types and climate conditions. As tarping grows in popularity among small, diversified farming operations, there is a need for extension information to assist growers to determine suitable uses across a wide range of crops, climates, and agroecosystems. Although tarping is a powerful tool for small-scale growers, it likely will not be implemented on large-scale operations without mechanizing the laying and removal steps. Mechanical and chemical weed management systems have legacy experience supporting them, but large-scale applications of plastic mulch indicate there is a market and appetite for alternative options. At present, tarps are an appropriate technology that can help small market growers meet many environmental and production goals. 


\section{Literature cited}

Batlla, D. and R.L. Benech-Arnold. 2014. Weed seed germination and the light environment: Implications for weed management. Weed Biol. Manage. 14:77-87, https://doi.org/10.1111/wbm.12039.

Birthisel, S.K. and E.R. Gallandt. 2019. Trials evaluating solarization and tarping for improved stale seedbed preparation in the northeast USA. Org. Farming 5:52-65, https://doi.org/10.12924/of2019.0501 0052 .

Birthisel, S.K., G.A. Smith, G.M. Mallory, J. Hao, and E.R. Gallandt. 2019. Effects of field and greenhouse solarization on soil microbiota and weed seeds in the northeast USA. Org. Farming 5:66-78, https://doi.org/10.12924/of2019.05010 066.

Blok, W.J., J.G. Lamers, A.J. Termorshuizen, and G.J. Bollen. 2000. Control of soilborne plant pathogens by incorporating fresh organic amendments followed by tarping. Phytopathology 90:253-259, https://doi.org/10.1094/PHYTO.2000. 90.3.253.

Bond, W. and A.C. Grundy. 2001. Nonchemical weed management in organic farming systems. Weed Res. 41:383-405, https://doi.org/10.1046/j.1365-3180. 2001.00246.x.

Borreani, G., S. Piano, and E. Tabacco. 2014. Aerobic stability of maize silage stored under plastic films with different oxygen permeability. J. Sci. Food Agr. 94:2684-2690, https://doi.org/10.1002/jsfa.6609.

Boyd, N.S., E.B. Brennan, and S.A. Fennimore. 2006. Stale seedbed techniques for organic vegetable production. Weed Technol. 20:1052-1057, https://doi. org/10.1614/WT-05-109.1.

Caldwell, B. and C.L. Mohler. 2001. Stale seedbed practices for vegetable production. HortScience 36:703-705, https:// doi.org/10.21273/hortsci.36.4.703.

Chandran, S., M.R. Unni, and S. Thomas. 2018. Organic farming: Global perspectives and methods. Woodhead Publ., Duxford, UK.

Dahlquist, R.M., T.S. Prather, and J.J. Stapleton. 2007. Time and temperature requirements for weed seed thermal death. Weed Sci. 55:619-625, https:// doi.org/10.1614/WS-04-178.1.

Davis, A.S. 2010. Cover-crop roller-crimper contributes to weed management in no-till soybean. Weed Sci. 58: 300-309, https://doi.org/10.1614/WSD-09-00040.1.

Domagała-Świątkiewicz, I. and P. Siwek. 2018. Effects of plastic mulches and high tunnel raspberry production systems on soil physicochemical quality indicators. Int. Agrophys. 32:39-47, https://doi. org/10.1515/intag-2016-0088.

Fulton, T.A., A.J. Hall, and J.L. Catley. 2001. Chilling requirements of Paeonia cultivars. Scientia Hort. 89:237-248, https://doi.org/10.1016/S0304-4238 (00)00237-5.

Gill, H.K., I.S. Aujla, L. De Bellis, and A. Luvisi. 2017. The role of soil solarization in India: How an unnoticed practice could support pest control. Front. Plant Sci. 8:1515, https://doi.org/10.3389/ fpls.2017.01515.

Granatstein, D., M.P. Brady, E.M. Kirby, and M. Ostrom. 2018. Trends in Washington state organic diversified vegetable production. 5 Dec. 2021. <http://hdl. handle.net/2376/13119>.

Hoyt, G.D., D.W. Monks, and T.J. Monaco. 1994. Conservation tillage for vegetable production. HortTechnology 4:129-135, https://doi.org/10.21273/ HORTTECH.4.2.129.

Hu, J., J. Wu, and X. Qu. 2018. Decomposition characteristics of organic materials and their effects on labile and recalcitrant organic carbon fractions in a semi-arid soil under plastic mulch and drip irrigation. J. Arid Land 10:115-128, https://doi.org/10.1007/s40333-0170035-1.

Hunter, R., J. Callaway, A. Rayburn, and G. Coffman. 2016. Tarping and inundation as potential control mechanisms for seed banks of red sesbania (Sesbania punicea). Invasive Plant Sci. Manag. 9:261271, https://doi.org/10.1614/IPSM-D16-00026.1.

Jacobs, J., J. Sciegienka, and F. Menalled. 2006. Ecology and management of anada thistle [Cirsium arvense (L.) Scop.]. 5 Dec. 2021. <https://permanent.fdlp.gov/ lps111272/nrcs144p2_052319.pdf $>$.

Javeed, H.M.R., M.S.I. Zamir, A. Tanveer, and M. Yaseen. 2013. Soil physical properties and grain yield of spring maize (Zea mays L.) as influenced by tillage practices and mulch treatments. Cercet. Agron. Mold. 46:69-75, https://doi.org/ 10.2478/v10298-012-0075-9.

Jerkins, D. and J. Ory. 2016. 2016 National organic research agenda: Outcomes and recommendations from the 2015 national organic farmer survey and listening sessions. 5 Dec. 2016. <https://ofrf.org/wpcontent/uploads/2019/09/NORA_ 2016_final9_28.pdf $>$.

Jones, A., J. Fortier, D. Gagnon, and B. Truax. 2020. Trading tree growth for soil degradation: Effects at 10 years of black plastic mulch on fine roots, earthworms, organic matter and nitrate in a multi- species riparian buffer. Trees Forests People 2:100032, https://doi.org/10.1016/ j.tfp.2020.100032.

Kasirajan, S. and M. Ngouajio. 2012. Polyethylene and biodegradable mulches for agricultural applications: A review. Agron. Sustain. Dev. 32:501-529, https://doi. org/10.1007/s13593-011-0068-3.

Kozłowski, J. and M. Kozłowska. 2008. Differences in acceptability of herb plants and oilseed rape for slugs (A. lusitanicus, $A$. rufus and $D$. reticulatum) in food choice tests. J. Plant Prot. Res. 48:461-474, https://doi.org/10.2478/vl0045-008-00 55-0.

Lamont, W.J. 2005. Plastics: Modifying the microclimate for the production of vegetable crops. HortTechnology 15:477-481, https://doi.org/10.21273/HORTTECH. 15.3.0477.

Lounsbury, N., N. Warren, S. Wolfe, and R. Smith. 2020. Investigating tarps to facilitate organic no-till cabbage production with high-residue cover crops. Renew. Agr. Food Syst. 35:227-233, https://doi.org/ $10.1017 /$ S1742170518000509.

Luna, J., J. Mitchell, and A. Shrestha. 2012. Conservation tillage for organic agriculture: Evolution toward hybrid systems in the western USA. Renew. Agr. Food Syst. 27:21-30, https://doi.org/ 10.1017/S1742170511000494.

Mashingaidze, A.B., O.A. Chivinge, and C. Zishiri. 1996. The effects of clear and black plastic mulch on soil temperature, weed seed viability and seedling emergence, growth and yield of tomatoes. J. Appl. Sci. South. Afr. 2:6-14, https:// doi.org/10.4314/jassa.v2il.16871.

Messiha, N.A.S., A.D. Diepeningen, M. Wenneker, A.R. Beuningen, J.D. Janse, G.C.M. Coenen, A.J. Termorshuizen, A.H.C. Bruggen, and W.J. Blok. 2007. Biological soil disinfestation (BSD), a new control method for potato brown rot, caused by Ralstonia solanacearum race 3 biovar 2. Eur. J. Plant Pathol. 117:403415, https://doi.org/10.1007/s10658007-9109-9.

Meulen, E.S., L. Nol, and L.H. Cammeraat. 2006. Effects of irrigation and plastic mulch on soil properties on semiarid abandoned fields. Soil Sci. Soc. Amer. J. 70:930-939, https://doi.org/10.2136/ sssaj2005.0167.

Mitch, L.W. Field bindweed. 1991. Weed Technol. 5:913-915. https://www.jstor. org/stable/3986918.

Mo, F., J. Han, X.X. Wen, X.K. Wang, P.F. Li, N. Vinay, Z.K. Jia, Y.C. Xiong, and Y.C. Liao. 2020. Quantifying regional effects of plastic mulch on soil nitrogen pools, cycles, and fluxes in rain- 
fed agroecosystems of the Loess Plateau. Land Degrad. Dev. 31:1675-1687, https://doi.org/10.1002/ldr.3548.

O'Hara, J. and M. Benson. 2019. Where have all the direct-marketing farms gone? J. Agric. Food Syst. Community Dev. 9(1):1-7, https://doi.org/10.5304/ jafscd.2019.091.046.

Orloff, N., J. Mangold, Z. Miller, and F. Menalled. 2018. A meta-analysis of field bindweed (Convolvulus arvensis L.) and canada thistle (Cirsium arvense L.) management in organic agricultural systems. Agr. Ecosyst. Environ. 254:264-272, https:// doi.org/10.1016/j.agee.2017.11.024.

Oryokot, J.O.E., S.D. Murphy, A.G. Thomas, and C.J. Swanton. 1997. Temperature- and moisture-dependent models of seed germination and shoot elongation in green and redroot pigweed (Amaranthus powellii, $A$. retroflexus). Weed Sci. 45:488-496, https://doi.org/10.1017/ S0043174500088718.

Qi, R., J. Li, Z. Lin, Z. Li, Y. Li, X. Yang, J. Zhang, and B. Zhao. 2016. Temperature effects on soil organic carbon, soil labile organic carbon fractions, and soil enzyme activities under long-term fertilization regimes. Appl. Soil Ecol. 102:36-45, https://doi.org/10.1016/j.apsoil.2016.02. 004.

Rylander, H., A. Rangarajan, R.M. Maher, M.G. Hutton, N.W. Rowley, M.T. McGrath, and Z.F. Sexton. 2020. Black plastic tarps advance organic reduced tillage I: Impact on soils, weed seed survival, and crop residue. HortScience 55:819-825, https://doi.org/10.21273/HORTSCI14 792-19.

Schonbeck, M., D. Jerkins, and J. Ory. 2017. Weed management: An ecological approach. 5 Dec. 2021. <https://ofrf.org/ soil-health-and-organic-farming-reports $/>$.

Seefeldt, S., C. Miles, E. Scheenstra, B. Maupin, M. Dolieslager, and T. Alexander. 2019. Control of "tall oatgrass" in organic vegetable production systems. 5 Dec. 2021. $<$ https://cahnrs.wsu.edu/research/grantresources/internal-competitive-grants/eri/ $>$.

Shahzad, K., A.I. Bary, D.P. Collins, L. Chalker-Scott, M. Abid, H.Y. Sintim, and M. Flury. 2019. Carbon dioxide and oxygen exchange at the soil-atmosphere boundary as affected by various mulch materials. Soil Tillage Res. 194:104335, https://doi. org/10.1016/j.still.2019.104335.

Sing, H. 2013. Soil carbon sequestration and rhizospheric microbial population in apricot orchards following plastic film mulching under cold arid region. Intl. J. Hort. 3:35-41.

Sintim, H.Y., S. Bandopadhyay, M.E. English, A. Bary, J.E. Liquet y González, J.M. DeBruyn, S.M. Schaeffer, C.A. Miles, and M. Flury. 2021. Four years of continuous use of soil-biodegradable plastic mulch: Impact on soil and groundwater quality. Geoderma 381:114665, https://doi.org/ 10.1016/j.geoderma.2020.114665.

Sintim, H.Y., S. Bandopadhyay, M.E. English, A.I. Bary, J.M. DeBruyn, S.M. Schaeffer, C.A. Miles, J.M. Reganold, and M. Flury. 2019. Impacts of biodegradable plastic mulches on soil health. Agr. Ecosyst. Environ. 273:36-49, https://doi. org/10.1016/j.agee.2018.12.002.

Stapleton, J.J. 2000. Soil solarization in various agricultural production systems. Crop Prot. 19:837-841, https://doi. org/10.1016/S0261-2194(00)00111-3.

Steele, R. 2017. Re-purposed used silage tarps: Surprisingly affordable, versatile. 5 Dec.
2021. < https://www.growingformarket. com/articles/repurposed-used-silage-tarpssurprisingly-affordable-versatile $>$.

Stone, C. 2015. The urban farmer: Growing food for profit on leased and borrowed land. New Society Publ., Gabriola, Canada.

Wang, L., X.G. Li, J. Lv, T. Fu, Q. Ma, W. Song, Y.P. Wang, and F.-M. Li. 2017. Continuous plastic-film mulching increases soil aggregation but decreases soil $\mathrm{pH}$ in semiarid areas of China. Soil Tillage Res. 167:46-53, https://doi.org/10.1016/j. still.2016.11.004.

Willeke, L., H. Krähmer, W. Claupein, and R. Gerhards. 2015. Sprouting ability and seasonal changes of sugar concentrations in rhizomes of Calystegia sepium and roots of Convolvulus arvensis. J. Plant Dis. Prot. 122:133-140, https://doi.org/ 10.1007/BF03356542.

Zhang, H., C. Miles, S. Ghimire, C. Benedict, I. Zasada, H. Liu, and L.W. DeVetter. 2020. Plastic mulches improved plant growth and suppressed weeds in late summer-planted floricane-fruiting raspberry. HortScience 55:565-572, https://doi. org/10.21273/HORTSCI14734-19.

Zhang, H., Q. Liu, X. Yu, G. Lu, and Y. Wu. 2012. Effects of plastic mulch duration on nitrogen mineralization and leaching in peanut (Arachis hypogea) cultivated land in the Yimeng Mountainous Area, China. Agr. Ecosyst. Environ. 158:164-171, https:// doi.org/10.1016/j.agee.2012.06.009.

Zwickle, S., R. Wilson, and D. Doohan. 2014. Identifying the challenges of promoting ecological weed management (EWM) in organic agroecosystems through the lens of behavioral decision making. Agr. Human Values 31:355-370, https://doi. org/10.1007/s10460-014-9485-7. 